\title{
Interoperabilita v GIS podle specifikací OGC
}

\author{
Radek Sklenička \\ Department of Mapping and Cartography \\ Faculty of Civil Engineering, CTU in Prague \\ E-mail: radek.sklenicka@fsv.cvut.cz
}

Klíčová slova: Open Geospatial Consortium, Geografické Informační Systémy, Web Processing Service, chaining web services

\begin{abstract}
Abstrakt
Trendem v oblasti Geografických informačních systémů je přechod z prostředi desktopových produkti̊ k distribuovaným GIS systémům, založeným převážně na potenciálu webových služeb. $V$ souvislosti s tím se hovoř́ o tzv. interoperabilitè. Zásadním subjektem, který podporuje interoperabilitu v GIS, je mezinárodní neziskové konsorcium Open Geospatial Consorcium,Inc. $(O G C)$. Konsorcium OGC vyviji specifikace aplikačnich prostředi a protokolu, které umožñují integraci v rámci aplikací, prostorových dat a služeb pro jejich zpracovávání. Jedním z aktuálně rešených problémů je vývoj modelu GIS, založeném na možnosti řetězení webových GIS služeb.
\end{abstract}

\section{Úvod}

Vývoj v oblasti Geografických informačních systémů směřuje k přechodu z prostředí desktopových produktů $\mathrm{k}$ distribuovaným GIS systémům, založeným převážně na potenciálu webových služeb. V souvislosti s tím se hovoří o tzv. interoperabilitě v GIS. Chápání interoperability přesahuje schopnost integrace nesourodých dat různých datových formátů, jde i o integraci na úrovni programových aplikací, webových i jiných služeb.

Zachovávání interoperability v GIS zajištuje vývoj standardů a specifikací a jejich používání. Jde jednak o standardizování datových formátů a struktur, ale také o standardy a specifikace pro definice výpočetních postupů, algoritmů, specifikace aplikačních rozhraní, protokolů a samozřejmě také webových služeb.

Jednou z nejdůležitějších organizací zabývajících se standardizací v Geografických informačních technologiích je konsorcium Open Geospatial Consorcium,Inc. (zkratka OGC).

OGC konsorcium nabízí specifikace pro GIS, které jsou zveřejněné a volně přístupné na domovských internetových stránkách OGC [1]. Tato otevřenost není nepodobná myšlence otevřenosti produktů Open Source a Free Software. V současné době si svět Geografickích informačních systému bez OGC specifikací dovede představit jen málokdo. Stejně to platí i Open Source a Free Software produktech.

Článek se zaměří na konsorcium OGC, poohlédne se po specifikacích běžně používaných v praxi, ale také zmíní ty, které se v běžné praxi teprve objeví. 


\section{Open Geospatial Consortium, Inc.}

Zásadní vliv na specifikace a standardizaci v GIS má několik konsorcií. Např́́klad konsorcium W3C (World Wide Web consortium) [3] se sice přímo standardizací v Geoinformatice nezabývá, ale má pro tento obor velký význam, nebot’ má zásadní vliv na vývoj interoperability ve webových technologiích vůbec. Mezi nejdůležitější subjekty, které se prrímo standardizací v Geoinformatice zabývají, patří ISO (International Organization for Standardization), INSPIRE (The INfrastructure for SPatial InfoRmation in Europe) a snad nejzásadnější vliv má OGC (Open Geospatial Consortium), viz. [1].

OGC je mezinárodní průmyslové neziskové konsorcium více než 300 obchodních společností, univerzit a vládních organizací, které společně usilují o interoperabilitu v oblasti Geografických informačních systémů a tzv. "Location Base" službách. OGC bylo založeno v roce 1994.

OGC vyvíjí specifikace aplikačních rozhraní a protokolů, které umožňují interoperabilitu v rámci aplikací, prostorových dat a služeb tzv. "geoprocessingu", tak jak je uvedeno v [2], v poznámce o OGC Specification Program.

\section{Vznik OGC specifikací}

Vznik OGC specifikací má jasně daný postup, daný směrnicí konsorcia. Předtím, než se řešený problém stane určitou OGC specifikací, projde širokou škálou fází vývoje, diskusí, praktickým testováním. Něž vyjde dokument s oficiálním statutem OGC specifikace, předchází mu dokumenty s označením např. discussion papers, recommendation papers.

\section{V praxi běžně používané OGC specifikace}

Pro připomenutí si uvedeme několik běžně používaných OGC specifikací; jde převážně o specifikace webových mapových služeb a dále specifikace datových formátů, definicí stylů a definic základních grafických objektů, které se v GIS vyskytují. Všechny specifikace jsou k dispozici na domovských internetových stránkách OGC, viz. [1].

\section{WMS}

Snad nejběžněji využívanou specifikací OGC konsorcia je dnes již všudypřítomná specifikace WMS (Web Map Service) webové služby, poskytující mapy v rastrovém formátu. Aby nedošlo k omylu; server se službou WMS neobsahuje pouze rastrová data, ale také vektorová data, často uložená v DBMS. Služba po požadavku klienta na mapový obsah vybere potřebná prostorová data a z těchto pak vygeneruje rastrový obraz a odešle jej.

\section{WFS}

Naproti tomu služba WFS (Web Feature Service) poskytuje i vektorová prostorová data v datovém formátu GML (Geographic Markup Language), který je další specifikací OGC.

Umožňuje tedy na rozdíl od WMS editaci prostorových dat na straně klienta.

\section{SLD}


SLD (Style Layer Descriptor), jak již název napovídá, definuje možnosti volby stylů poskytovaných datových vrstev, které si uživatel podle potřeby nadefinuje. SLD rozšiřuje možnosti WMS.

\section{SFS}

SFS (Simple Features Specification) určuje způsob definice základních grafických objektů, které se v GIS vyskytují (bodů, linií, polygonů, povrchů ...) a dále potom základní prostorové vazby mezi nimi (průsečík, překrytí, styk, ...). Existují tři implementační specifikace pro rozhraní OLE/COM, CORBA a dotazovací jazyk SQL.

\section{Z geodetického pohledu zajímavé specifikace}

Z geodetického pohledu jsou zajímavé specifikace, které se zabývají otázkou souřadnicových referenčních systémů a transformacemi souřadnic.

\section{Spatial referencing by coordinates}

Tato OGC specifikace zároveň supluje navrhovaný mezinárodní ISO standard 19111 Geographic information - Spatial referencing by coordinates.

Definuje souřadnicové referenční systémy a operace mezi nimi. Tak jak je známo z geodézie, definuje např. referenční elipsoid, geodetické datum, geoid, geocentrické soư̌adnice, elipsoidické výšky, atd.

\section{Coordinate Transformation Services}

Implementační OGC specifikace definující aplikační rozhraní pro práci se souřadnicovými systémy a transformacemi mezi souřadnicovými systémy. Existují implementace pro Java třídy a pro rozhraní CORBA a COM. Tato specifikace vlastně ukazuje programátorům, jakým způsobem vyvíjet software pro operace s souřadnicovými systémy. Existující kompletní implementace této specifikace je obsažena v javovské sadě tříd pro vývoj GIS aplikací GeoTools, viz. http://www.geotools.org/.

\section{Web Coordinate Transformation Service (WCTS)}

Jde o návrh implementační specifikace (zatím tzv. discussion paper) pro webovou službu, která poskytuje transformace mezi souřadnicovými systémy. Dle základní architektury webových služeb OGC konsorcia (OWS), viz. dále, poskytuje služba jednak základní popis nabídky svých možností, jako např. podporované souřadnicové systémy, podporované operace mezi zvolenými souřadnicovými systémy a také umožňuje provést zvolenou transformaci. To vše přes dotazy GetCapabilities, IsTransformable, Transform.

Implementaci WCTS vyvíjí např. známý Open Source vývojár̆ Frank Warmerdam, viz. [4]. Další implementaci WCTS lze nalézt například na adrese http://geobrain.laits.gmu.edu/cgibin/WCTS/wcts. 


\section{OpenGIS Web Services (OWS) architektura}

Ve výše uvedených sekcích byly vypsány některé OGC specifikace webových služeb, které se již běžně v praxi využívají nebo jsou ve fázi testování a vývoje. Mohli bychom jistě připojit i další, například WCS (Web Coverage Service) služba se již také běžně využívá. Pro ilustraci uved'me ještě WTS (Web Terrain Service),

Web3D (Web 3D Service), WRS (Web Registry Server).

Specifikací webových služeb stále přibývá a je vhodné, aby měly nějaký společný definiční rámec. Proto existuje specifikace OpenGIS Web Services Common Specification (OWS), která tento obecný rámec pro webové specifikace definuje. Specifikuje několik aspektů společných pro implementace webových služeb. Jde o rámec určitých daných parametrů a obsahu klientských požadavků (např. GetCapabilities) a datových struktur, které služba vrací (requests and responses). Nad tento společný rámec definuje implementace konkrétní služby své vlastní parametry a strukturu dat. Pro ilustraci uved’me požadavek, který vrací souhrnný popis dané služby. Jde o známý dotaz GetCapabilities, který lze nalézt v implementacích služeb WMS, WFS, WCS, WPS, WCTS a dalších.

\section{Web Processing Service (WPS)}

Navrhovaná specifikace (zatím tzv. discussion paper) webové služby poskytuje přes webové rozhraní přístup k širší škále GIS operací.

Rozšiřuje možnosti od pouhého poskytování a prezentaci prostorových dat, k možnostem jejich zpracování a provádění různých výpočetních úkonů.

Služba je zaměřena na zpracovávání rastrových a vektorových prostorových dat.

WPS nespecifikuje konkrétní úlohu a konkrétní požadovaná vstupní a výstupní data, ale poskytuje obecný mechanismus k popisu široké škály různých výpočetních úkonů, obecný mechanismus pro popis potřebných vstupních a výstupních dat požadovaných klientem služby.

V souladu s architekturou OWS, operuje klient s prostředky služby prostřednictvím následujících tří operací.

\section{GetCapabilities}

Tato operace vrací popis (v XML dokumentu) služby, výčet dostupných výpočetních procesů a jejich verzí. Dotaz tohoto požadavku vypadá následovně:

http://server.foo/foo?SERVICE=WPS\&REQUEST=GetCapabilities\&VERSION=0 . 2.1

\section{DescribeProcess}

Na tento požadavek vrací server detailní popis jednoho či více dostupných procesů, spolu s popisem vstupních a výstupních dat.

Pro ilustraci opět úplný zápis dotazu:

http://server. foo/foo?SERVICE=WPS\&REQUEST=DescribeProcess\&VERSION=0 . 2.1

\&ProcessName $=\mathrm{xxx}$

\section{Execute}


Execute spustí požadovaný proces (výpočetní úkon) a vrátí požadovaná výstupní data.

\section{Chaining web services}

Dalším krokem kupředu je možnost řetězení webových služeb, tzv. "Chaining web services". Snahou je založit webové služby na společných specifikacích a standardech a tak umožnit jejich spojování na úrovni server - server, a dále jejich kaskádování a různé kombinování. Úroveň tohoto spojování klade velký důraz na precizní popis jednotlivých služeb. Do hry přichází jazyky a rozhraní pro popis webových služeb jako je WSDL ( Wed Service Description Language) [5], UDDI (Universal Description, Discovery and Integration) [6].

Hovoří se o ontologii a o semantickém webu vůbec. V případě OGC uved’me př́́klad navrhované specifikace ve stádiu tzv. discussion paper, a to OWS 2 - Common Architecture: WSDL SOAP UDDI.

\section{Závěr}

Přechod z prostředí desktopových produktů k distribuovaným GIS systémům využívajících webových služeb jde ruku v ruce s rychlým vývojem webových technologií. Nutností je zachování interoperability, postavené na definování specifikací a standardů a jejich používání. Hlavním subjektem, který se zabývá specifikacemi v oblasti GIS, je konsorcium Open Geospatial Consortium, Inc. (OGC). Základní architekturu specifikací OGC webových služeb tvoří OpenGIS Web Services Common Specification (OWS), která vytváří společný obecný rámec pro webové služby.

Vyvíjí se specifikace služeb WPS (Web Processing Service), které dále rozšsiří možnosti využití funkčnosti GIS v prostředí webu. Do fáze testování vchází technologie řetězení webových GIS služeb.

Model distribuovaných GIS, založený na možnosti různých kombinací webových služeb, umožní uživatelům flexibilně vytvářet vlastní GIS řešení. Tento model je založen na nejnovějších a rapidně se vyvíjejících webových technologiích a tak kam půjde vývoj ve kterých určitých př́padech ukáže teprve čas.

\section{Reference}

1. Open Geospatial Consortium,Inc. ${ }^{1}$ - Open Geospatial Consortium,Inc. Home Page [200605-10]

2. Technical Committee Policies and Procedures, document OGC 05-020r4, Open Geospatial Consortium,Inc., 2005, url: Online ${ }^{2}$ [2006-05-10]

3. W3C - Worl Wide Web consortium ${ }^{3}$ - W3C - Worl Wide Web consortium Home Page [2006-05-10]

\footnotetext{
${ }^{1}$ http: //www .opengeospatial.org/

${ }^{2}$ http://www . opengeospatial .org/about/?page=tcpp

${ }^{3}$ http://www.w3.org/
} 
4. OGR WCTS Implementation ${ }^{4}$ - OGR WCTS Implementation Home Page [2006-05-10]

5. E. Christensen, F. Curbera, G. Meredith, and S. Weerawarana, "Web Services Description Language (WSDL) 1.1", W3C Note, 2001, url: Online ${ }^{5}$ [2006-05-10]

6. UDDI Project ${ }^{6}$ - UDDI Project Home Page [2006-05-10]

\footnotetext{
${ }^{4}$ http://home.gdal.org/projects/wcts/

${ }^{5}$ http://www . w3.org/TR/wsdl

${ }^{6}$ http: //www . uddi.org
} 